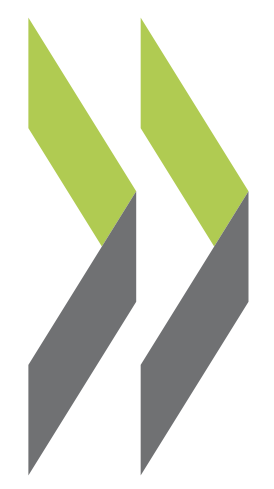

OECD Economics Department Working Papers No. 794

Is there a Case for CarbonBased Border Tax Adjustment? An Applied General Equilibrium

\section{Jean-Marc Burniaux,}

Jean Château, Romain Duval

\title{
Analysis
}


Organisation de Coopération et de Développement Économiques

Organisation for Economic Co-operation and Development

21-Jul-2010

ECONOMICS DEPARTMENT

English - Or. English

IS THERE A CASE FOR CARBON-BASED BORDER TAX ADJUSTMENT?

AN APPLIED GENERAL EQUILIBRIUM ANALYSIS

ECONOMICS DEPARTMENT WORKING PAPERS No. 794

By Jean-Marc Burniaux, Jean Chateau and Romain Duval

All Economics Department Working Papers are available through OECD's Internet website at http://www.oecd.org/eco/Workingpapers 


\begin{abstract}
RÉSUMÉ
Is there a case for carbon-based border tax adjustment? An applied general equilibrium analysis

Concern that unilateral greenhouse gas emission reductions could foster carbon leakage and undermine the international competitiveness of domestic industry has led to growing calls for carbon-based border-tax adjustments (BTAs). This paper uses a global general equilibrium model to assess the economic effects of BTAs and comes to three main conclusions. First, BTAs can reduce carbon leakage if the coalition of countries taking action to reduce emissions is small, because in this case leakage (while typically small) mainly occurs through international trade competitiveness losses rather than through declines in world fossil fuel prices that trigger rising carbon intensities outside the region taking action. Second, the welfare impacts of BTAs are small, and typically slightly negative at the world level. Third, and perhaps more strikingly, BTAs do not necessarily curb the output losses incurred by the domestic energy intensive-industries (EIIs) they are intended to protect in the first place. This is in part because taken as a whole, EIIs in industrialised countries make important use of carbon-intensive intermediate inputs produced by EIIs in other geographical areas. Another, deeper explanation is that EIIs are ultimately more adversely affected by carbon pricing itself, and the associated contraction in market size, than by any international competitiveness losses. These findings are shown to be robust to key model parameters, country coverage and design features of BTAs.
\end{abstract}

JEL classification: Q54; H25; D58

Keywords: Climate change; mitigation; border tax adjustment; computable general equilibrium model.

*************************

\title{
Y-a-t-il un argument en faveur d'une taxe carbone aux frontières ? Une analyse d'équilibre général
}

Les craintes que des réductions unilatérales d'émissions de gaz à effet de serre soient en partie compensées par des fuites de carbone tout en ayant un effet négatif sur la compétitivité des industries domestiques ont entraîné des appels croissants en faveur de taxes carbone aux frontières (TCFs). Cet article utilise un modèle d'équilibre général appliqué pour évaluer les effets économiques des TCFs et aboutit à trois conclusions. Premièrement, les TCFs peuvent réduire les fuites de carbone lorsque la coalition de pays prenant des mesures de réduction des émissions est réduite, car dans ce cas les fuites carbone (quoique typiquement faibles) se produisent essentiellement via des pertes de compétitivité internationale, plutôt que via des baisses du prix mondial des énergies fossiles qui entraînent une hausse de l'intensité en carbone dans le reste du monde. Deuxièmement, les impacts des TCFs sur le bien-être sont faibles, et typiquement légèrement négatifs au niveau mondial. Troisièmement, et peut-être de façon plus frappante, les TCFs n'atténuent pas nécessairement les pertes de production subies par les industries domestiques intensives en énergie (IIEs) qu'elles sont pourtant censées protéger. Cela tient en partie à ce que prises dans leur ensemble, les IIEs dans les pays industrialisés utilisent de façon importante des intrants intensifs en carbone produits par les IIEs d'autres zones géographiques. Une autre explication plus profonde est que les IIEs sont in fine davantage touchées par l'existence d'un prix du carbone lui-même, et par la contraction de la taille du marché qui s'en suit, que par de quelconques pertes de compétitivité internationale. Ces résultats s'avèrent robustes à des hypothèses alternatives concernant certains paramètres clé du modèle, les pays couverts et les modalités de mise en place des TCFs.

Classification JEL: Q54; H25; D58Mots-clé: Changement climatique; atténuation; taxe carbone aux frontières ; modèle d'équilibre général calculable.

Copyright OECD 2010

Application for permission to reproduce or translate all, or part of, this material should be made to: Head of Publications Service, OECD, 2 rue André-Pascal, 75775 Paris Cedex 16, France. 


\section{TABLE OF CONTENTS}

\begin{tabular}{|c|c|}
\hline $\begin{array}{l}\text { Is there a ca } \\
\text { equilibrium }\end{array}$ & se for carbon-based border tax adjustment? An applied general \\
\hline 1. Introduc & tion and executive summary \\
\hline 2. Two illu & 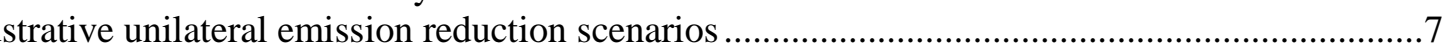 \\
\hline 3. The imp & act of BTAs on carbon leakage, the output of EIIs and welfare \\
\hline 4. Generali & 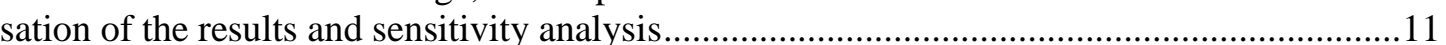 \\
\hline 5. Conclus & ion \\
\hline References ... & 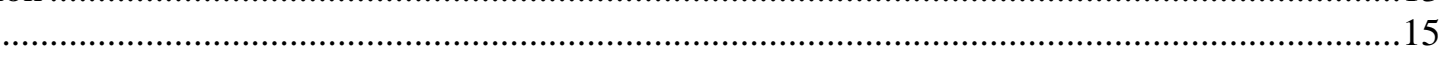 \\
\hline nnex 1. An & 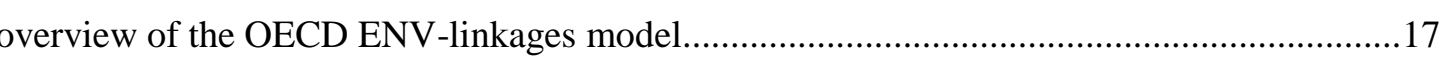 \\
\hline References .. & 20 \\
\hline Annex 2. Con & 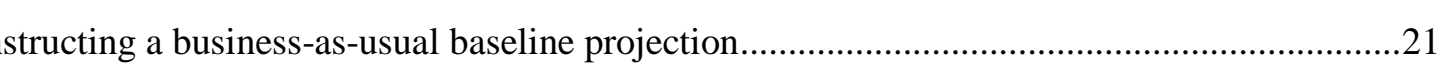 \\
\hline Tables & \\
\hline Table 1. & Two benchmark scenarios of the impact of BTAs in $2030 \ldots \ldots$ \\
\hline Table 2. & Impact of Border Tax Adjustments under alternative implementation assumptions ................ 12 \\
\hline Table 3. & 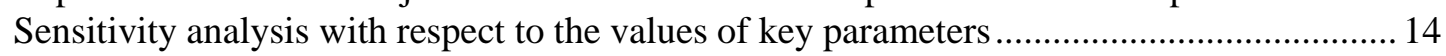 \\
\hline Table A1.1. & 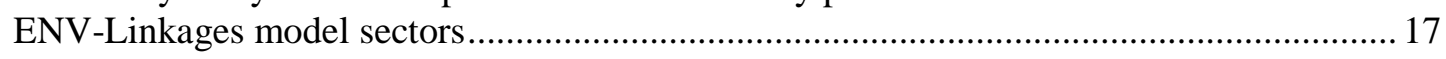 \\
\hline Table A1.2. & 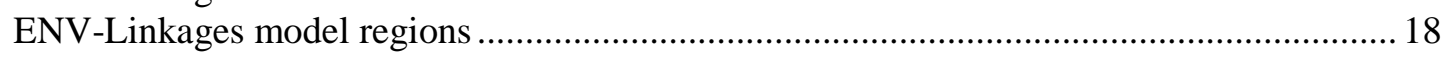 \\
\hline
\end{tabular}

\section{Figures}

Figure A2.1. Projected GHG emissions1 by country/region (2005-50, Gt CO2eq) 
ECO/WKP(2010)50 
ECO/WKP(2010)50

\title{
IS THERE A CASE FOR CARBON-BASED BORDER TAX ADJUSTMENT? AN APPLIED GENERAL EQUILIBRIUM ANALYSIS
}

\author{
By Jean-Marc Burniaux, Jean Chateau and Romain Duval ${ }^{1}$
}

\section{Introduction and executive summary}

Anthropogenic climate change is a global public bad that calls for a global policy answer. Yet, partly reflecting strong free-riding incentives, the immediate prospects for a global carbon price addressing the negative externality associated with greenhouse gas (GHG) emissions are weak. Policy action is proceeding only gradually, with only some of the main emitting countries taking on binding policy measures. The COP15 held in Copenhagen in 2009 confirmed that global climate policy action will likely be built out of a collection of fragmented domestic commitments. At the same time, growing concern in industrialised countries that such unilateral reductions could foster "carbon leakage" and undermine the international competitiveness of domestic industries have led to growing calls for border-tax adjustments (BTAs) to "level the playing field", particularly in the European Union (EU) and the United States (US). BTAs could take several forms, such as taxing imports or forcing importers to surrender emission allowances under domestic emission trading schemes (ETS). Computing the carbon content of imported goods that would be subject to BTAs could be undertaken in a number of ways. Regulators could attempt to estimate the direct carbon content of imports, the total embodied carbon including inputs in the value chain or the content of comparable domestic goods. None of these measures is straightforward.

Neither is the environmental rationale for BTAs, notwithstanding the participation incentives they might provide by punishing free-riding. There is a fairly broad consensus from the computable general equilibrium (CGE) literature that carbon leakage is limited, at least under plausible assumptions about key parameters such as carbon supply and trade elasticities (see in particular Burniaux and Oliveira Martins, 2000), and some papers have even explored the possibility of reverse leakage through endogenous technological change and international technology spillovers to non-mitigating countries (Grubb et al., 2002; Gerlagh and Kuik, 2007). ${ }^{2}$ There is a much clearer political economy rationale, however. Even

1. The authors are Senior Economist at the OECD Environment Directorate, Economist at the OECD Environment Directorate and Head of Division at the OECD Economics Department, respectively. They would like to thank Cuauhtemoc Rebolledo-Gómez and Olivier Besson for excellent statistical and editing support, and Jan Corfee-Morlot, Rob Dellink, Jorgen Elmeskov, Stéphanie Jamet, Christine de la Maisonneuve, Helen Mountford, John Stephenson and Simon Upton for their input, suggestions and comments. Any errors are the responsibilities of the authors alone. The views expressed in this paper are those of the authors, and do not necessarily reflect those of the OECD or of its member countries.

2. The focus of this literature, including the present paper, is on leakage across space. Some recent studies have stressed that more leakage might in fact occur across time through an inter-temporal channel. With finite fossil fuel endowments, pricing carbon today and announcing higher prices tomorrow gives carbon producers incentives to raise supply today, possibly leading to an increase rather than a decline in world emissions (Sinn, 2008). This mechanism is found to be even larger under incomplete geographical coverage of carbon pricing (Eichner and Pethig, 2009). 
though leakage may be small overall, domestic energy-intensive industries exposed to international competition (EIIs) may still incur sizeable competitiveness and output losses from unilateral emission reduction action, especially in oligopolistic sectors producing an homogenous tradable good (Babikker, 2005; Demailly and Quirion, 2006, 2008a, 2008b). EIIs have been lobbying hard for BTAs in both the EU and the US, with the result that some recent BTA proposals focus essentially on these industries.

So far the economic debate on BTAs has mostly centered on administrative feasibility and consistency with WTO rules, and on compatibility with free trade more broadly (De Cendra, 2006; Demaret and Stewardson, 1994; Goh, 2004; Ismer and Neuhoff, 2007; Perez, 2007 Stiglitz, 2006). However, surprisingly little economic analysis has been performed to assess the actual economic effects of BTAs. Based on earlier literature on the equivalence between origin and destination based sales taxes (Dosser, 1967 Krauss and Johnson, 1972, Shibata, 1967) and its implications for the effects of BTAs (Grossman, 1980; Whalley, 1979), Lockwood and Whalley (2008) discuss the economics of carbon-based BTAs. They stress that under a number of restrictive conditions (not least the absence of labour-leisure choice), and provided they apply similarly to all goods, (non carbon based) economy-wide BTAs have only nominal effects, without any real effects on production, consumption and trade. By contrast, carbon-based BTAs distort relative prices because the carbon content of goods differs and, therefore, they cannot be neutral. As a result, abstracting from their possible environmental effects, implementing a BTA along with a domestic carbon tax yields a welfare loss relative to a no-domestic-carbon-tax / no-BTA scenario. Whether BTAs also imply a welfare loss relative to a carbon-tax / no-BTA scenario is less straightforward in theory, as in this case BTAs may partly correct for the distortion associated with applying a carbon tax only to domestic goods. ${ }^{3}$ The effects of BTAs are therefore largely an empirical matter.

How BTAs are computed also matters. In principle, the domestic carbon price in the country acting unilaterally should be applied to the total (direct and indirect) carbon content of imported goods from a given country of origin. Although such calculation can in principle be completed within the framework of a world CGE model, it is unlikely to be feasible to implement it in practice. Partly for this reason, the handful of studies that have attempted to quantify the impact of carbon-based BTAs using CGE models have assumed different ways to calculate BTAs. For instance, Dong and Whalley (2009) build a small illustrative four-region two-sector computable general equilibrium (CGE) model, and find beneficial effects of BTAs on leakage but only small impacts on welfare and production for the EU and the US. This is partly because they assume BTAs to be applied based on the direct carbon content of domestically produced goods (in the EU and US), rather than on the (often much higher) carbon content of comparable imported goods. Mattoo et al. (2009) explore a broader range of options using a more detailed CGE framework, and find larger impacts of BTAs in some scenarios. But here again, it is a matter of how BTAs are modelled. In the benchmark scenarios of the present paper, the carbon content used to calculate BTAs is that of the country of origin of the imported good, and it includes both the direct carbon content based on fossil fuel inputs and the part of the indirect content that corresponds to fossil fuel inputs into the electricity used as intermediate consumption in the particular sector and country subject to the BTA. Alternative setups are also considered as part of an extensive sensitivity analysis.

This paper uses a global recursive-dynamic CGE model, ENV-Linkages, to assess the impacts of BTAs on leakage, competitiveness and welfare. Given the empirical nature of the issue, and the central role played by interactions across countries and sectors through trade and fossil fuel price channels, an applied global CGE framework appears to be the appropriate analytical tool. Two benchmark scenarios are

3. This is over and above any potential environmental benefits - resulting from reduced carbon leakage and thereby increased global emission reductions - from BTAs, which are not included in the welfare analysis performed in this paper. However, such gains are unlikely to radically alter our conclusions, as the unilateral targets considered below amount to a modest mitigation of worldwide emissions, a small share of which is subject to leakage. 
considered under which either the EU alone or the group of Annex I countries under the Kyoto Protocol (mostly industrialised countries) cut their emissions by $20 \%$ by 2020 and $50 \%$ by 2050 relative to 2005 levels. Consistent with recent legislative initiatives and political economy fundamentals, special attention is paid to EIIs throughout the analysis. Importantly, a broad-based sensitivity analysis is performed to assess the robustness of the main results to key model parameters, targets, countries and design features of BTAs.

Two main conclusions stand out. First, BTAs can reduce carbon leakage for small coalitions of acting countries such as the EU, because in this case leakage (while typically small) mainly occurs through international trade competitiveness losses rather than through declines in world fossil fuel prices. However, the need for, and the effectiveness of BTAs declines rapidly with the size of the coalition as BTAs address a smaller share of an ever smaller rate of leakage. Second, the economic effects of BTAs are small. They have negligible welfare effects both worldwide and for countries that impose them. This is not wholly unexpected given that their effects are theoretically ambiguous. Perhaps more strikingly, BTAs do not necessarily curb the output losses incurred by the domestic EIIs they are intended to support in the first place. This is in part because in industrialised countries, EIIs make important use of carbon-intensive intermediate inputs produced by EIIs in other geographical areas. Another, deeper explanation is that EIIs are ultimately more adversely affected by carbon pricing itself - which is needed to achieve a costeffective reduction in emissions - and the associated contraction in market size, than by any international competitiveness losses and the associated reduction in market share.

The rest of this paper proceeds as follows. Section 2 assesses leakage, welfare and competitiveness losses from unilateral emission reduction action under the two benchmark scenarios. Section 3 explores the effects of introducing BTAs under these scenarios, and Section 4 performs sensitivity analysis of the main results to key model parameters, targets and design features of BTAs. Section 5 concludes.

\section{Two illustrative unilateral emission reduction scenarios}

The assessment of the economic effects of BTAs relies in a first step - before carrying out extensive sensitivity analysis in a second step - on two benchmark climate policy scenarios, under which either the EU alone or Annex I countries under the Kyoto Protocol as a whole cut their emissions by $20 \%$ by 2020 and by $50 \%$ by 2050 , relative to 2005 levels. At the 2020 horizon, the former scenario (scenario "EU no BTA" in Table 1) corresponds in fact to the official EU emission reduction target. ${ }^{4}$ The latter scenario (scenario "A1 no BTA" in Table 1) is more illustrative, and aims at exploring possible differences in the magnitude of leakage and the economic effects of BTAs between smaller and larger coalitions of acting countries. Reflecting the likely magnitude and unpredictability of long-term changes in the structure of the world economy, as well as the very low probability that a small number of countries will act alone over a horizon of several decades anyway, the main focus is on the 2030 horizon. Results at the 2020 horizon are qualitatively similar but quantitatively smaller, reflecting a less stringent target - and therefore a lower carbon price - at this horizon.

4. The EU has indicated that this target could be raised from $20 \%$ to $30 \%$ if other countries took on "comparable efforts". Note that the EU target is defined as a percentage of 1990 levels, but since emissions in 2005 are globally identical to 1990 for the region as a whole, this difference does not matter. 
ECO/WKP(2010)50

Table 1. Two benchmark scenarios of the impact of BTAs in 2030

(Emissions reduction profile: $-\mathbf{2 0 \%}$ in 2020 and $-50 \%$ in 2050 for acting countries, relative to 2005 levels)

\begin{tabular}{|c|c|c|c|c|c|c|c|c|c|}
\hline \multirow{2}{*}{ Policy scenario } & \multirow{2}{*}{$\begin{array}{c}\text { Carbon tax } \\
\left(\mathrm{USD} / \mathrm{t} \mathrm{CO}_{2}\right)\end{array}$} & \multirow{2}{*}{$\begin{array}{l}\text { Leakage } \\
\text { rate (\%) }\end{array}$} & \multicolumn{3}{|c|}{ Equivalent variation in income } & \multicolumn{3}{|c|}{ Ell output } & \multirow{2}{*}{$\begin{array}{l}\text { World GHG } \\
\text { emissions }\end{array}$} \\
\hline & & & World & $\begin{array}{l}\text { non-acting } \\
\text { countries }\end{array}$ & $\begin{array}{l}\text { acting } \\
\text { countries }\end{array}$ & World & $\begin{array}{l}\text { non-acting } \\
\text { countries }\end{array}$ & $\begin{array}{l}\text { acting } \\
\text { countries }\end{array}$ & \\
\hline
\end{tabular}

\section{$\%$ change in 2030 with respect to the baseline}

Reference scenarios

EU no BTA EU countries acting alone

EU BTA dir EU countries acting alone + BTA on direct carbon contents

EU BTA ind EU countries acting alone + BTA on direct and indirect carbon contents

A1 no BTA Annexl countries acting alone

A1 BTA dir Annexl countries acting alone + BTA on direct carbon contents

A1 BTA ind Annexl countries acting alone + BTA on direct and indirect carbon contents

\begin{tabular}{rrrrrrrrr}
61 & 7.9 & -0.4 & -0.1 & -1.4 & -0.2 & 0.2 & -2.2 & -2.4 \\
63 & 1.0 & -0.4 & -0.1 & -1.2 & -0.3 & 0.2 & -2.5 & -2.6 \\
63 & -1.4 & -0.4 & -0.2 & -1.1 & -0.3 & 0.1 & -2.5 & -2.6 \\
74 & 5.9 & -1.2 & -0.5 & -1.6 & -0.9 & 1.1 & -3.2 & -12.6 \\
74 & 3.4 & -1.2 & -0.8 & -1.5 & -1.1 & 0.9 & -3.4 & -13.0 \\
74 & 2.2 & -1.3 & -1.0 & -1.4 & -1.2 & 0.6 & -3.3 & -13.1 \\
\hline
\end{tabular}

Source: OECD ENV-Linkages model 
Scenarios EU no BTA and A1 no BTA are both simulated using the OECD's ENV-Linkages model, a global recursive-dynamic CGE model featuring 12 world regions and 22 sectors, and including both $\mathrm{CO} 2$ and non-CO2 GHGs. The main features of the model are discussed in Annex 1 and in greater detail in Burniaux and Chateau (2008), while the baseline (no-carbon-price / no-BTA) scenario that underpins it, is briefly described in Annex 2 and in full in Duval and de la Maisonneuve (2010). The welfare impacts of policy action are measured relative to baseline using the Hicksian equivalent variation in income to assess changes in real income. These utility-based welfare measures do not incorporate the impacts of climate change, which are not covered in ENV-Linkages. While such impacts are subject to broad uncertainty and are small anyway at the 2030 horizon of this paper, this should be borne in mind when interpreting the results from the welfare analyses performed below. Throughout the analysis special attention is also paid to EIIs, which include here chemicals, non-ferrous metals, fabricated metal products, iron and steel, pulp and paper and non-metallic mineral products. The effects of both scenarios on leakage, real income (Hicksian equivalent variation in income) and the real output of EIIs are presented in Table 1. Leakage is found to be small and to decline with coalition size, reaching just $8 \%$ of the decline in EU emissions by 2030 in scenario "EU no BTA", and 6\% of the decline in Annex I emissions in scenario "A1 no BTA". ${ }^{5}$ Moreover, it is not only the magnitude but also the nature of leakage that changes with the size of the coalition. Indeed leakage can arise through two main channels: the international trade channel, as carbon-intensive industries in acting countries lose market shares to their foreign competitors and/or relocate capital in non-acting countries; the fossil fuel price channel, as emission reduction efforts in acting countries lower world demand for fossil fuels, thereby inducing a price decline that triggers greater fossil fuel use and higher GHG emissions in non-participating countries. The wider the country coverage, the smaller the market share losses affecting EIIs in participating countries (the international trade channel of leakage), but the larger the impact of policy action on international fossil fuel prices (the fossil fuel price channel of leakage).

The negative welfare impact of achieving the target is smaller for the EU (scenario "EU no BTA") than for Annex I countries as a whole (scenario "A1 no BTA"), reflecting the faster baseline emissions growth and higher carbon intensity of the latter group of countries. As would be expected, qualitatively similar, but quantitatively larger impacts are found for the output of EIIs.

\section{The impact of BTAs on carbon leakage, the output of EIIs and welfare}

The impacts of implementing a BTA under the two benchmark scenarios are now simulated using the ENV-Linkages model. BTAs should in principle apply to the actual carbon content of imported goods, rather than to the carbon content of comparable domestic goods. Therefore the former set up is retained, although the latter is also analysed in Section 4 as it might be easier to implement in practice. Another issue is the extent to which BTAs would apply not only to the direct carbon content of goods but also to their indirect content, i.e. to the carbon content of the inputs used to produce these goods. While in theory they could be simulated with ENV-Linkages as they are in Mattoo et al. (2009), in practice accurately calculating the full indirect carbon content of goods is likely to be impossible, especially given the length and complexity of value added chains in an increasingly globalised production process. Therefore two more realistic alternatives are considered here, namely BTAs applied either only to the direct carbon content of (imported) goods (Scenarios "EU BTA dir" and "A1 BTA dir") or to the direct plus part of the indirect content via the carbon content of electricity inputs only ( Scenarios "EU BTA ind" and "A1 BTA ind").

The results are presented in Table 1. BTAs appear to reduce the carbon leakage from the unilateral emission reduction measures of small coalitions, but their effectiveness declines rapidly with coalition size.

5. Note that the lower leakage rate in scenario "A1 no BTA" compared with scenario "EU no BTA" is not entirely straightforward a priori, because the $20 \%$ emission reduction objective under both scenarios implies a larger absolute cut (in giga tons $\mathrm{CO}_{2}$ equivalent, $\mathrm{Gt} \mathrm{CO}_{2}$-eq) than in the former. 
Indeed the (limited) leakage problem is fully addressed in the EU case (scenarios "EU BTA dir" and "EU BTA ind"), ${ }^{6}$ but less so when a larger coalition such as Annex I countries takes action (scenarios "A1 BTA dir" and "A1 BTA ind"). This is primarily because under smaller coalitions, leakage arises comparatively more from international competitiveness losses than through a decline in world fossil fuel prices, making BTAs a more effective tool since they address the former but not the latter channel. As a result of the leakage reduction, the environmental effectiveness of unilateral actions in terms of world emissions reduction is improved, although only marginally.

By contrast, the economic effects of BTAs are found to be fairly small overall in both scenarios. BTAs mitigate the welfare losses from carbon pricing for acting countries, but at the world level these gains are roughly offset by additional losses in the rest of the world. When BTAs are applied at the level of Annex I countries, the real income loss incurred by non-Annex I countries is somewhat higher, reaching $1 \%$ of their real income. As noted above, negligible welfare effects from BTAs in the countries that implement them are not entirely unexpected from theory, as their impact is a priori ambiguous and driven by the difference in - not the level of - the tariffs applied across goods. ${ }^{7}$

Perhaps more surprisingly, despite some effectiveness in reducing leakage, BTAs are not found to curb the output losses of EIIs taken as a whole (relative to a carbon tax/no BTA scenario). The output losses incurred by EIIs in both scenarios are roughly unchanged when either the direct or both the direct and indirect carbon contents of imports are subject to a border tariff. This is in part because several factors contribute to offset the positive output effects of the market share gains associated with BTAs: first and foremost, since domestic EIIs (taken as a whole) in industrialised countries rely heavily on imported inputs produced by EIIs at a different level of the value added chain in other countries, BTAs increase the production costs of domestic EIIs; ${ }^{8}$ second, realistic but incomplete forms of BTAs such as those considered here, which do not cover the full indirect carbon content of imports, do not fully address the competitiveness losses of domestic EIIs; third, the presence of BTAs induces a slight increase in the carbon price to meet the domestic emission target, which further increases the production costs of EIIs. However, as will become apparent in Section 4 below, the single most important factor behind the lack of effectiveness of BTAs to support domestic EIIs is that these industries are ultimately more adversely affected by the existence of carbon pricing itself than by any international competitiveness losses.

6. The EU is even found to experience "negative leakage" once BTAs are implemented. This is because the supply of coal is more elastic than that of crude oil in the benchmark calibration of ENV-Linkages, making coal relatively more expensive in world international markets when emission reduction measures - both direct and indirect such as BTAs - are taken by a reasonably large area such as the EU. This induces a substitution away from more carbon-intensive coal in non-participating countries, and therefore a decline in their emissions that amounts to negative carbon leakage.

7. In the literature, the impact of GHG mitigation policies is sometimes reported in terms of GDP changes, although GDP is a less appropriate metric to measure welfare changes than the real income indicator used in Table 1. When expressed in terms of GDP, the impact of BTAs implies a slight increase in economic costs for acting countries, for instance from a GDP loss of $0.8 \%$ to $0.9 \%$ in 2030 in the scenario where the $\mathrm{EU}$ is acting alone. Real-exchange-rate and international trade changes account for this difference between the GDP and real income effects of BTAs. However, both indicators convey the same message that the economic effects of BTAs are small in the countries that implement them.

8. Partly for this reason, unlike other EIIs, the mineral (including cement) and non-ferrous metal industries which rely less than other EIIs on carbon-intensive imported inputs - are found to gain somewhat from BTAs. 


\section{Generalisation of the results and sensitivity analysis}

In order to assess the extent by which the results from Section 3 can be generalized, sensitivity analysis is carried out by applying BTAs to other OECD countries, exploring alternative options for implementing them and considering alternative values for some critical model parameters.

The first panel of Table 2 reports impacts of BTAs under unilateral action by the USA (scenarios "US no BTA" and "US BTA ind") and Japan (scenarios "JPN no BTA" and "JPN BTA ind"). While US BTAs yield a significantly smaller reduction in carbon leakage compared with the EU BTAs ${ }^{9}-$ from 12 to $9 \%$ in 2030, other results regarding real income and EIIs output effects are in line with those from the benchmark scenarios of Section 3. In particular, BTAs have little impact on mitigation costs and are ineffective in curbing the output losses incurred by EIIs, for reasons discussed above.

The second panel of Table 2 examines the consequences of alternative ways of implementing BTAs. For instance BTAs could be based on the carbon content of domestic rather than imported goods, as this would likely improve the practical feasibility of BTAs. Using domestic carbon contents (scenarios "EU BTA ind dom" and "A1 BTA ind dom" in Table 2) implies for the EU and Annex I countries a much smaller reduction in carbon leakage compared with the two benchmark scenarios of Section 3. In both cases, domestic carbon contents in acting countries are lower than those of imported goods due to a more efficient use of fossil fuels, and this results into smaller BTAs. While the environmental effectiveness of applying BTAs on this basis is therefore reduced, the economic costs of action in terms of real income and EIIs output losses are unchanged or even slightly increased.

BTAs on imports alone only partly address competitiveness concerns in acting countries as they fail to compensate for the competitiveness losses that domestic EIIs would incur on their export markets. In principle, this issue could be addressed through a symmetrical treatment of EIIs' imports and exports, which would involve BTAs on imports along with some exemption of EIIs exports from the domestic carbon price. In practice, however, such a measure is found to have little impact on EIIs output losses (scenarios "EU BTA ind sub" and "A1 BTA ind sub" in Table 2), while increasing the overall economic losses incurred by acting countries, due to the higher carbon price that results from the narrower coverage of carbon pricing. As carbon leakage tends to increase with a higher carbon price, the environmental effectiveness of BTAs is also slightly reduced.

Similarly, restricting mitigation action to $\mathrm{CO} 2$ emissions from fuel combustion only (rather than comprehensive mitigation across all greenhouse gases) requires much higher taxes (scenarios "EU no BTA $\mathrm{CO} 2$ " and "A1 no BTA CO2" in Table 2) and implies significantly higher leakage rates: leakage rates calculated for all GHGs in 2030 reach 14\% for the EU and 9\% for Annex I countries, versus 8\% and 6\% respectively if mitigation involves all GHGs. This illustrates the role of $\mathrm{CO} 2$ and the importance of the world energy markets in generating carbon leakages. The impact of BTAs (scenarios "EU BTA ind CO2" and "A1 BTA ind CO2") under CO2 mitigation only is in line with previous results, namely: the leakage rate is reduced (especially in the case of the EU); the real income loss in acting countries is slightly lower and offset at the world level by higher losses in other countries; there is no reduction in the output losses incurred by EIIs in acting countries.

9. This reflects the smaller weight of the competitiveness versus fossil fuel component in the leakage generated by US action, as the US economy is both less open to trade and accounts for a bigger share of world fossil fuel consumption than the EU. 
ECO/WKP(2010)50

Table 2. Impact of Border Tax Adjustments under alternative implementation assumptions

\begin{tabular}{|c|c|c|c|c|c|c|c|c|c|c|}
\hline \multirow{2}{*}{\multicolumn{2}{|c|}{ Policy scenario }} & \multirow{2}{*}{$\begin{array}{c}\text { Carbon tax } \\
\left(\mathrm{USD}_{\mathrm{t}} \mathrm{CO}_{2}\right)\end{array}$} & \multirow{2}{*}{$\left|\begin{array}{c}\text { Leakage rate } \\
(\%)\end{array}\right|$} & \multicolumn{3}{|c|}{ Equivalent variation in income } & \multicolumn{3}{|c|}{ Ell output } & \multirow{2}{*}{$\begin{array}{l}\text { World GHG } \\
\text { emissions }\end{array}$} \\
\hline & & & & World & $\begin{array}{l}\text { non-acting } \\
\text { countries }\end{array}$ & acting countries & World & $\begin{array}{l}\text { non-acting } \\
\text { countries }\end{array}$ & acting countries & \\
\hline & & & & \multicolumn{7}{|c|}{$\%$ change in 2030 with respect to the baseline } \\
\hline \multicolumn{11}{|c|}{ Alternative countries } \\
\hline US no BTA & USA acting alone & 73 & 11.8 & -0.4 & -0 . & -1.2 & -0.3 & 0.6 & -4.6 & -5.2 \\
\hline US BTA ind & USA acting alone + BTA & 75 & 8.6 & -0.4 & -0 & -1.0 & -0.4 & 0.4 & -4.6 & -5.4 \\
\hline JPN no BTA & Japan acting alone & 30 & 12.5 & -0.1 & 0. & -0.4 & 0.0 & 0.1 & -1.4 & -0.5 \\
\hline JPN BTA ind & Japan acting alone + BTA & 31 & 5.5 & -0.1 & 0. & -0.3 & 0.0 & 0.1 & -1.4 & -0.6 \\
\hline \multicolumn{11}{|c|}{ Alternative options for implementing BTAS } \\
\hline EU BTA ind dom & EU acting alone + BTA based on domestic carbon content & 62 & 5.2 & -0.4 & -0 . & -1.3 & -0.3 & 0.2 & -2.5 & -2.5 \\
\hline A1 BTA ind dom & Annex I countries acting alone + BTA based on domestic carbon content & 74 & 4.5 & -1.3 & -0 . & -1.6 & -1.1 & 1.1 & -3.6 & -12.8 \\
\hline EU BTA ind sub & EU acting alone + BTA exempting exports & 64 & -0.9 & -0.4 & -0 . & -1.3 & -0.3 & 0.2 & -2.3 & -2.6 \\
\hline A1 BTA ind sub & Annexl countries acting alone + BTA exempting exports & 75 & 3.6 & -1.3 & -0 & -1.6 & -1.2 & 0.8 & -3.4 & -12.9 \\
\hline EU no BTA CO2 & EU acting alone with $\mathrm{CO}_{2}$ only & 79 & 13.5 & -0.4 & -0 . & -1.7 & -0.2 & 0.2 & -2.1 & -1.7 \\
\hline EU BTA ind $\mathrm{CO} 2$ & EU acting alone with $\mathrm{CO}_{2}$ only $+\mathrm{BTA}$ & 82 & 0.9 & -0.5 & -0. & -1.4 & -0.3 & 0.2 & -2.5 & -1.9 \\
\hline A1 no BTA CO2 & Annexl countries acting alone with $\mathrm{CO}_{2}$ only & 86 & 9.1 & -1.2 & -0 . & -1.6 & -0.9 & 1.3 & -3.3 & -9.8 \\
\hline A1 BTA ind $\mathrm{CO} 2$ & Annexl countries acting alone with $\mathrm{CO}_{2}$ only $+\mathrm{BTA}$ & 87 & 4.7 & -1.3 & -1 . & -1.5 & -1.2 & 0.9 & -3.4 & -10.4 \\
\hline EU BTA ind diag & EU acting alone with BTA and exempting diagonal imported input & 64 & -1.6 & -0.4 & -0 . & -1.1 & -0.3 & 0.1 & -1.9 & -2.6 \\
\hline A1 BTA ind diag & Annexl countries acting alone with BTA and exempting diagonal imported input & 74 & 2.2 & -1.3 & -1 . & -1.4 & -1.1 & 0.5 & -3.0 & -13.1 \\
\hline
\end{tabular}

Source: OECD ENV-Linkages model 
The last two scenarios (scenarios "EU BTA ind diag" and "A1 BTA ind diag") in Table 2 show that a marginally more effective way to curb EIIs' output losses in acting countries would be to exempt from the BTA their imported inputs of EII products originating from trading partners. However, such an approach would reduce EIIs' output losses only marginally compared with the benchmark scenarios, from $2.2 \%$ to $1.9 \%$ in 2030 in the EU and from 3.3\% to 3\% in Annex I countries. The small magnitude of this gain confirms that the primary driver of EIIs' output losses in countries that take mitigation action is the impact of carbon pricing on production costs, rather than any loss in international competitiveness.

Finally, Table 3 shows that these results are reasonably robust to alternative values of key parameters. In a nutshell, alternative parameter values do alter the environmental and economic effects of carbon taxes, but they have a more limited influence on the impact of BTAs, which is measured relative to those carbon price scenarios. A more (less) elastic supply of fossil fuels at the world level implies lower (higher) leakage from unilateral mitigation action. The effectiveness of BTAs in reducing carbon leakage is reduced under a less elastic fossil fuel supply, especially in the scenario where Annex I countries act alone (scenarios "A1 no BTA" and "A1 BTA ind" in Table 3). However, previous results regarding the economic effects of BTAs still hold. The degree of product differentiation in world trade markets also influences the amount of carbon leakage. If products from different origins are more substitutable (as simulated by raising the values of the Armington elasticities), carbon leakage is higher and the loss of competitiveness incurred by EIIs results in a larger output loss (scenarios "EU no BTA" in Table 3 and Table 1). Still, the environmental and economic impacts of the BTAs remain roughly unchanged.

\section{Conclusion}

As industrialised countries implement or consider more stringent unilateral constraints on domestic GHG emissions, the political momentum for BTAs to address carbon leakage and "level the playing field" between their EIIs and their unconstrained foreign competitors might grow. A small body of recent economic research that builds on earlier literature on border adjustments points to ambiguous and probably small welfare effects of BTAs a priori, but this has yet to be backed by fully-fledged applied analyses. This paper began to fill this gap by using a global recursive-dynamic CGE model, ENV-Linkages, to assess the potential impacts of BTAs on leakage, competitiveness and welfare. Illustrative unilateral emission reduction scenarios with and without BTAs are explored, and extensive sensitivity analysis is performed in order to assess the robustness of the results to targets, countries, design features of BTAs and key parameters such as fossil fuel supply or international trade elasticities. A robust finding across all simulations is that BTAs have only small welfare effects. They have also typically no beneficial impact on the output of the EIIs they are intended to support in the first place. BTAs primarily reduce the demand for, and thereby the output of the foreign competitors of domestic EIIs, leading to a mechanical increase in the global market share of domestic EIIs. However this does not bring any output gains since the positive impact of competitiveness gains is typically offset by a rise in production costs, and both effects are small anyway compared with the output losses associated with the existence of a carbon price. Under most circumstances, BTAs are more effective at reducing carbon leakage, and the environmental gains from lower global emissions are not factored into the welfare analysis performed in this paper. However, such gains are unlikely to radically alter the conclusions, as the unilateral targets considered here amount to a modest mitigation of worldwide emissions, a small share of which is subject to leakage. Finally, it should be stressed that the findings from this paper do not incorporate, and therefore come over and above existing concerns regarding the administrative costs and retaliation risks that BTAs may entail. 
Table 3. Sensitivity analysis with respect to the values of key parameters

\begin{tabular}{|c|c|c|c|c|c|c|c|c|c|c|}
\hline & \multirow{3}{*}{ Policy scenario } & \multirow{3}{*}{$\begin{array}{c}\text { Carbon tax } \\
\left(\mathrm{USD} / \mathrm{t} \mathrm{CO}_{2}\right) \\
\text { in } 2030\end{array}$} & \multirow{3}{*}{$\begin{array}{c}\text { Leakage rate (\%) } \\
\text { in } 2030\end{array}$} & \multicolumn{7}{|c|}{$\%$ change in 2030 with respect to the baseline } \\
\hline & & & & \multicolumn{3}{|c|}{ Equivalent variation in income } & \multicolumn{3}{|c|}{ Ell output } & \multirow{2}{*}{$\begin{array}{l}\text { World GHG } \\
\text { emissions }\end{array}$} \\
\hline & & & & World & $\begin{array}{c}\text { non-acting } \\
\text { countries }\end{array}$ & acting countries & World & $\begin{array}{l}\text { non-acting } \\
\text { countries }\end{array}$ & acting countries & \\
\hline \multicolumn{11}{|c|}{ Sensitivity to price elasticity of fossil fuel supply } \\
\hline EU no BTA & Fossil fuel supply more elastic & 59 & 5.2 & -0.4 & -0.1 & -1.5 & -0.2 & 0.2 & -2.2 & -2.5 \\
\hline EU BTA ind & Fossil fuel supply more elastic & 61 & -4.1 & -0.4 & -0.2 & -1.2 & -0.4 & 0.1 & -2.4 & -2.7 \\
\hline EU no BTA & Fossil fuel supply less elastic & 66 & 13.6 & -0.3 & -0.1 & -1.4 & -0.2 & 0.3 & -2.3 & -2.2 \\
\hline EU BTA ind & Fossil fuel supply less elastic & 68 & 4.3 & -0.4 & -0.2 & -1.1 & -0.3 & 0.2 & -2.6 & -2.5 \\
\hline A1 no BTA & Fossil fuel supply more elastic & 70 & 4.2 & -1.3 & -0.5 & -1.7 & -1.0 & 1.0 & -3.2 & -12.9 \\
\hline A1 BTA ind & Fossil fuel supply more elastic & 70 & 2.8 & -1.3 & -0.7 & -1.7 & -1.2 & 0.9 & -3.6 & -13.0 \\
\hline A1 no BTA & Fossil fuel supply less elastic & 80 & 9.5 & -1.1 & -0.4 & -1.4 & -0.9 & 1.3 & -3.3 & -12.1 \\
\hline A1 BTA ind & Fossil fuel supply less elastic & 81 & 8.1 & -1.1 & -0.6 & -1.4 & -1.1 & 1.3 & -3.7 & -12.3 \\
\hline \multicolumn{11}{|c|}{ Sensitivity to Armington Elasticities (AE) } \\
\hline EU no BTA & Low AE for manufacturing goods in all countries & 62 & 7.5 & -0.4 & -0.1 & -1.4 & -0.2 & 0.2 & -2.0 & -2.4 \\
\hline EU BTA ind & Low AE for manufacturing goods in all countries & 64 & -2.1 & -0.4 & -0.2 & -1.1 & -0.4 & 0.1 & -2.4 & -2.6 \\
\hline EU no BTA & High AE for manufacturing goods in all countries & 61 & 8.8 & -0.4 & -0.1 & -1.5 & -0.3 & 0.3 & -2.5 & -2.4 \\
\hline EU BTA ind & High AE for manufacturing goods in all countries & 63 & -0.4 & -0.4 & -0.2 & -1.2 & -0.4 & 0.2 & -2.6 & -2.6 \\
\hline A1 no BTA & Low AE for manufacturing goods in all countries & 74 & 5.3 & -1.2 & -0.6 & -1.5 & -1.0 & 0.8 & -3.0 & -12.7 \\
\hline A1 BTA ind & Low AE for manufacturing goods in all countries & 74 & 1.5 & -1.3 & -1.1 & -1.4 & -1.3 & 0.4 & -3.3 & -13.2 \\
\hline A1 no BTA & High AE for manufacturing goods in all countries & 73 & 6.9 & -1.2 & -0.4 & -1.6 & -0.9 & 1.6 & -3.7 & -12.5 \\
\hline A1 BTA ind & High AE for manufacturing goods in all countries & 73 & 3.2 & -1.3 & -0.9 & -1.5 & -1.2 & 0.9 & -3.5 & -13.0 \\
\hline
\end{tabular}

Source: OECD ENV-Linkages model (spring 2010 baseline) 
ECO/WKP(2010)50

\section{REFERENCES}

Babiker M.H. (2005), "Climate Change Policy, Market Structure, and Carbon Leakage", Journal of International Economics, Vol. 65.

Burniaux, J-M. and J. Chateau (2008), "An Overview of the OECD ENV-Linkages Model”, OECD Economics Department Working Papers No. 653, OECD, Paris.

Burniaux J-M. and J. Oliveira Martins (2000), "Carbon Emission Leakages: A General Equilibrium View", OECD Economics Department Working Papers No. 242, OECD, Paris.

Demailly D. and P. Quirion (2008a),"European Emission Trading Scheme and competitiveness: A case study on the iron and steel industry", Energy Economics, Vol. 30.

Demailly, D. and P. Quirion (2008b), "Leakage from Climate Policies and Border Tax Adjustment: Lessons from a Geographic Model of the Cement Industry", in R. Guesnerie and H. Tulkens (Eds.), The Design of Climate Policy, CESifo Seminar Series, The MIT Press, Boston.

Demailly, D. and P. Quirion, (2006), "CO2 Abatement, Competitiveness and Leakage in the European Cement Industry Under the EU-ETS: Grandfathering vs. Output-based Allocation", Climate Policy, Vol. 6.

De Cendra, J. (2006) "Can Emissions Trading Schemes be Coupled with Border Tax Adjustments? An Analysis Vis-à-vis WTO Law", Review of European Community and International Environmental Law, Vol. 15.

Demaret, P. and R. Stewardson (1994), "Border Tax Adjustments under GATT and EC Law and General Implications for Environmental Taxes", Journal of World Trade, Vol. 28.

Dong, Y. and J.Whalley (2009), "How Large Are the Impacts of Carbon Motivated Border Tax Adjustments?”, NBER Working Paper No. 15613.

Dosser D. (1967) "Economic Analysis of Tax Harmonization”, in C.S. Shoup (Ed.), Fiscal Harmonization in Common markets, Vol. I, Theory, Columbia University Press, New York.

Duval, R. and C. de la Maisonneuve (2010), "A Long-Run Growth Framework and Scenarios for the World Economy", Journal of Policy Modeling, Vol. 62.

Eichner, T. and R. Pethig (2009), "Carbon Leakage, the Green Paradox and Perfect Future Markets", CESifo Working Paper No. 2542.

Gerlagh, R. and O. Kuik (2007), “Carbon Leakage with International Technology Spillovers”, FEEM Working Papers No. 33.2007, FEEM, Venice.

Goh, Gavin (2004), "The World Trade Organization, Kyoto and Energy Tax Adjustments at the Border", Journal of World Trade, Vol. 38. 
ECO/WKP(2010)50

Grossman, G.M. (1980), “BTA: Do They Distort Trade?”, Journal of International Economics, Vol. 10.

Grubb M., C.Hope, and R.Fouquet (2002), "Climatic Implications of the Kyoto Protocol: The Contribution of International Spillover”, Climatic Change, Vol. 54.

Ismer, R. and K. Neuhoff (2007), "Border Tax Adjustment: A Feasible Way to Support Stringent Emission Trading", European Journal of Law and Economics, Vol. 24.

Krauss, M. B. \& H. G. Johnson (1972), "The Theory of Tax Incidence: A Diagrammatic Analysis,” Economica, Vol. 39.

Lockwood, B. and J.Whalley (2008), "Carbon Motivated Border Tax Adjustments: Old Wine in Green Bottles?”, NBER Working Paper No. 14025.

Mattoo, A., A. Subramanian, D. van der Mensbrugghe and J. He (2009), "Reconciling Climate change and Trade Policy",World Bank Policy Research Working Paper No. WPS5123, World Bank, Washington D.C.

OECD (2009), The Economics of Climate Change Mitigation: Policies and Options for Global Action Beyond 2012, OECD, Paris.

Perez, R. (2007), “Towards a Generalized System of Environmental Tariffs?”, mimeo, United Nations, New York.

Shibata, H. (1967), "The Theory of Economic Unions: A Comparative Analysis of Customs Unions, Free Trade Areas, and Tax Unions", in C.S. Shoup (ed.), Fiscal Harmonization in Common markets, Vol. I, Theory, Columbia University Press, New York.

Sinn, H.-W. (2008), "Public policies against global warming", International Tax and Public Finance, Vol. 15.

Stiglitz, J. (2006), “A New Agenda for Global Warming, The Economists’ Voice No. 3.

Whalley, J. (1979) “Uniform Domestic Tax Rates, Trade Distortions and Economic Integration” Journal of Public Economics, Vol. 11. 
ECO/WKP(2010)50

\section{ANNEX 1. AN OVERVIEW OF THE OECD ENV-LINKAGES MODEL}

The OECD ENV-Linkages model is a recursive dynamic neo-classical general equilibrium model. It is the successor to the OECD GREEN model for environmental studies (Burniaux, et al. 1992; Burniaux, 2000). The model is documented in Burniaux and Chateau (2008). Previous works using ENV-Linkages extensively include two books: OECD (2008) and OECD (2009).

ENV-Linkages is a global economic model built primarily on a database of national economies. In the version of the model used here, the world economy is divided in 12 countries/regions, each with 25 economic sectors (Tables A1.1 and A1.2), including five different technologies to produce electricity. The core of the static equilibrium is formed by the set of Social Account Matrices (SAMs) that describes how economic sectors are linked; these are based on the GTAP database (currently using version 6.2). A fuller description of the database can be found at Dimaranan (2006). Many key parameters are set on the basis of information drawn from various empirical studies and data sources (see Burniaux and Chateau, 2008).

Table A1.1. ENV-Linkages model sectors

\begin{tabular}{ll}
\hline 1) Rice & 14) Food Products \\
2) Other crops & 15) Other Mining \\
3) Livestock & 16) Non-ferrous metals \\
4) Forestry & 17) Iron \& steel \\
5) Fisheries & 18) Chemicals \\
6) Crude Oil & 19) Fabricated Metal Products \\
7) Gas extraction and distribution & 20) Paper \& Paper Products \\
8) Fossil Fuel Based Electricity & 21) Non-Metallic Minerals \\
9) Hydro and Geothermal electricity & 22) Other Manufacturing \\
10) Nuclear Power & 23) Transport services \\
11) Solar\& Wind electricity & 24) Services \\
12) Renewable combustibles and waste electricity & 25) Construction \& Dwellings \\
13) Petroleum \& coal products & 26) Coal \\
\hline
\end{tabular}

All production in ENV-Linkages is assumed to operate under cost minimisation with an assumption of perfect markets and constant returns to scale technology. The production technology is specified as nested Constant Elasticity of Substitution (CES) production functions in a branching hierarchy. Each sector uses intermediate inputs - including energy inputs - and primary factors (labour, capital, land and natural resources). For each good or service, output is produced by different production streams which are differentiated by capital vintage (old and new). The substitution possibilities among production factors are assumed to be higher with the new than with the old capital vintages - technology has a putty/semi-putty specification. Capital accumulation is modelled according to the traditional Solow/Swan neo-classical growth model. 
Table A1.2. ENV-Linkages model regions

\begin{tabular}{|c|c|}
\hline ENV-Linkages regions & GTAP countries/regions \\
\hline 1) Australia \& New Zealand & Australia, New Zealand \\
\hline 2) Japan & Japan \\
\hline 3) Canada & Canada \\
\hline 4) United States & United States \\
\hline 5) European Union 27 \& EFTA & $\begin{array}{l}\text { Austria, Belgium, Denmark, Finland, Greece, Ireland, Luxembourg, } \\
\text { Netherlands, Portugal, Sweden, France, Germany, United Kingdom, Italy, } \\
\text { Spain, Switzerland, Rest of EFTA, Czech Republic, Slovakia, Hungary, Poland, } \\
\text { Romania, Bulgaria, Cyprus, Malta, Slovenia, Estonia, Latvia, Lithuania }\end{array}$ \\
\hline 6) Brazil & Brazil \\
\hline 7) China & China, Hong Kong \\
\hline 8) India & India \\
\hline 9) Russia & Russian Federation \\
\hline 10) Oil-exporting countries & $\begin{array}{l}\text { Indonesia, Venezuela, Rest of Middle East, Islamic Republic of Iran, Rest of } \\
\text { North Africa, Nigeria }\end{array}$ \\
\hline $\begin{array}{l}\text { 11) Non-EU Eastern European } \\
\text { countries }\end{array}$ & Croatia, Rest of Former Soviet Union \\
\hline 12) Rest of the world & $\begin{array}{l}\text { Korea, Taiwan, Malaysia, Philippines, Singapore, Thailand, Viet Nam, Rest of } \\
\text { East Asia, Rest of Southeast Asia, Cambodia, Rest of Oceania, Bangladesh, } \\
\text { Sri Lanka, Rest of South Asia, Pakistan, Mexico, Rest of North America, } \\
\text { Central America, Rest of Free Trade Area of Americas, Rest of the Caribbean, } \\
\text { Colombia, Peru, Bolivia, Ecuador, Argentina, Chile, Uruguay, Rest of South } \\
\text { America, Paraguay, Turkey, Rest of Europe, Albania, Morocco, Tunisia, Egypt, } \\
\text { Botswana, Rest of South African Customs Union, Malawi, Mozambique, } \\
\text { Tanzania, Zambia, Zimbabwe, Rest of Southern African Development } \\
\text { Community, Mauritius, Madagascar, Uganda, Rest of Sub-Saharan Africa, } \\
\text { Senegal, South Africa. }\end{array}$ \\
\hline
\end{tabular}

The energy bundle is of particular interest for analysis of climate change issues. Energy is a composite of fossil fuels and electricity. In turn, fossil fuel is a composite of coal and a bundle of the "other fossil fuels". At the lowest nest, the composite "other fossil fuels" commodity consists of crude oil, refined oil products and natural gas. The value of the substitution elasticities are chosen as to imply a higher degree of substitution among the other fuels than with electricity and coal.

World trade is based on a set of regional bilateral flows. Allocation of trade between partners responds to changes in relative prices between regions. The basic assumption is that imports originating from different regions are imperfect substitutes (Armington specification). Each region runs a fixed current-account surplus (or deficit).

The ENV-Linkages model has a simple recursive-dynamic structure, where households base their decisions on static expectations concerning prices and quantities. Household consumption demand and savings are implemented through an "Extended Linear Expenditure System". Since consumers are not represented with forward-looking behavior, some care needs to be exercised in studying policies that consumers may reasonably be expected to anticipate - either the policy itself or its consequences. In each period, investment net-of-economic depreciation is equal to the sum of government savings, consumer savings and net capital flows from abroad.

The government in each region collects various kinds of taxes in order to finance government expenditures. Aggregate government expenditures are linked to real GDP. Assuming fixed public savings (or 
deficits), the government budget is balanced through the adjustment of the income tax on consumer income.

$\mathrm{CO}_{2}$ emissions from combustion of energy are directly linked to the use of different fuels in production. Other GHG emissions are linked to output in a way similar to Hyman et al. (2002). The following non- $\mathrm{CO}_{2}$ emission sources are considered: $i$ ) methane from rice cultivation, livestock production (enteric fermentation and manure management), coal mining, crude oil extraction, natural gas and services (landfills); ii) nitrous oxide from crops (nitrogenous fertilizers), livestock (manure management), chemicals (non-combustion industrial processes) and services (landfills); iii) industrial gases (SF6, PFC's and HFC's) from chemicals industry (foams, adipic acid, solvents), aluminum, magnesium and semiconductors production.

For studying the impacts of climate change policy, four types of instruments have been developed: 1) GHG taxes, global or specific by sectors, gases or emission sources; 2) tradable emission permits (with flexibility between regions and sectors); 3 ) offsets (including a stylised version of the Clean Development Mechanism); and 4) regulatory policy. Taxes and tradable permits are applied directly to GHG emissions. Offsets are driven by an exogenous limit on demand for offset credits and competition between potential suppliers. Regulatory policy has been introduced in the model through quantity constraints (Burniaux, et al. 2008).

Market goods equilibria imply that, on the one side, the total production of any good or service is equal to the demand addressed to domestic producers plus exports; and, on the other side, the total demand is allocated between the demands (both final and intermediary) addressed to domestic producers and the import demand. The general equilibrium framework ensures that a unique set of relative prices emerges such that demand equals supply in all markets simultaneously (i.e. across all regions, commodities, and factors of production). All prices are expressed relatively to the numéraire of the price system that is chosen as the index of OECD manufacturing exports prices. Implementation of a policy in the model leads to a new equilibration process and thus a new set of equilibrium prices and quantities to compare with the original equilibrium.

The process of calibration of the ENV-Linkages model is broken down into three stages (cf. Burniaux and Chateau, 2008). First, a number of parameters are calibrated, given some elasticity values, on baseyear (2001) values of variables. Second, the 2001 database is updated to 2005 by simulating the model dynamically to match historical trends over the period 2001-05; thus all variables are expressed in 2005 real USD. Third, the baseline projection until 2050 is based on convergence assumptions about labour productivity and other socio-economic drivers (demographic trends, future trends in energy prices and energy efficiency gains), as further described in Duval and de la Maisonneuve (2010). The baseline has been adjusted to incorporate the effects of the economic crisis of 2008-09. In addition, the baseline assumes no new climate policies, but does include other government policies for instance on energy policy as included in the energy projections of the IEA (2009). ${ }^{10}$ It thus provides a benchmark against which policy scenarios aimed at achieving emission cuts can be assessed.

10. The baseline simulation also contains the assumption that the EU Emission Trading System is implemented over the period 2006-12, assuming a permits price that will rise gradually from 5 to 25 constant \$US in 2012 . 


\section{REFERENCES}

Burniaux, J-M., (2000), “A Multi-Gas Assessment of The Kyoto Protocol”, OECD Economics Department Working Papers No. 270.

Burniaux, J-M. and J. Chateau. (2008), An overview of the OECD ENV-Linkages Model. OECD Economics Department Working Papers No 653.

Burniaux, J-M., G. Nicoletti and J. Oliveira Martins (1992), "GREEN: A Global Model for Quantifying the Costs of Policies to Curb CO2 Emissions", OECD Economic Studies, 19 (Winter).

Dimaranan, B.V., Editor (2006), Global Trade, Assistance, and Production: The GTAP 6 Data Base, Center for Global Trade Analysis, Purdue University.

Duval, R. and C. de la Maisonneuve (2010), "A Long-Run Growth Framework and Scenarios for the World Economy", Journal of Policy Modeling 62, pp. 64-80.

Hyman, R.C., J.M. Reilly, M.H. Babiker, A. De Masin, and H.D. Jacoby (2002), "Modeling Non-CO2 Greenhouse Gas Abatement", Environmental Modeling and Assessment, Vol. 8, No. 3, pp. 175-86.

IEA (2009), World Energy Outlook, International Energy Agency, Paris.

OECD (2008), OECD Environmental Outlook to 2030, OECD, Paris.

OECD (2009), The Economics of Climate Change Mitigation: Policies and Options for Global Action Beyond 2012, OECD, Paris. 
ECO/WKP(2010)50

\section{ANNEX 2. CONSTRUCTING A BUSINESS-AS-USUAL BASELINE PROJECTION}

\section{Assumptions about drivers of GDP}

Baseline economic scenarios underlying climate change projections - such as those developed for the IPCC (Nakicenovic et al., 2000) - typically assume that there will be some gradual convergence of income levels towards those of most developed economies. A similar approach is taken here, but special emphasis is put on integrating some of the current theoretical and empirical knowledge on long-term economic growth, and making transparent assumptions about the drivers of GDP growth over the projection period (for discussion of assumptions, detailed results and data sources, see Duval and de la Maissonneuve, 2010).

A "conditional convergence" hypothesis is incorporated into the projections. Following past research (e.g. Hall and Jones, 1999; Easterly and Levine, 2001), and based on a standard aggregate Cobb-Douglas production function with physical capital, human capital, labour and labour-augmenting technological progress, GDP per capita is first decomposed as follows for 2005:

$$
Y_{t} / \text { Pop }_{t}=\left(K_{t} / Y_{t}\right)^{\alpha /(1-\alpha)} A_{t} h_{t}\left(L_{t} / \text { Pop }_{t}\right)
$$

where Yt/Popt, Kt/Yt, At, ht, and Lt/Popt denote the level of GDP per capita (using PPP exchange rates to convert national GDPs into a common currency), the capital/output ratio, total factor productivity (TFP), human capital per worker and the employment rate, respectively. $\alpha$ is the capital share in aggregate output.

Based on this, long-term projections are then made for each of the four components so as to project the future path of GDP per capita:

- Long-term annual TFP growth at the "frontier", defined as the average of the "high-TFP" OECD countries, is $1.5 \%$. The speed at which other countries converge to that frontier is assumed to tend gradually towards $2 \%$ annually.

- Where it is currently highest, the human capital of the 25-29 age group is assumed to level off, based on past experience. The speed at which other countries converge to that frontier is assumed to tend gradually towards a world average between 1960 and 2000. The human capital of the working-age population is then projected by cohorts.

- Capital/output ratios in all countries gradually converge to current levels in the United States, which is implicitly assumed to be on a balanced growth path. In other words, marginal returns to capital converge across countries over the very long term in a world where international capital is mobile.

- Employment projections combine population, participation and unemployment scenarios. The United Nations population projections are used (baseline scenario). In those OECD countries where participation is currently highest, future retirement ages are partially indexed to life expectancy. Elsewhere, participation rates gradually converge to the average in "frontier" countries. Unemployment rates converge to $5 \%$.

This framework was applied to 76 countries, covering $90 \%$ of the world's GDP and population in 2005. For all other countries, the productivity convergence scenario to labour productivity or GDP per capita was applied instead of TFP. The approach followed addresses recent criticisms of economic 
projections using market exchange rates, which form the vast majority of scenarios in the literature (Castles and Henderson, 2003a, 2003b; Henderson, 2005). This is achieved in two ways: (i) By using purchasing power parities (PPPs), not market exchange rates, to compare initial income per capita levels; (ii) by assuming faster future productivity growth in tradable than in non-tradable industries, in line with historical patterns. Reflecting this "Baumol-Balassa-Samuelson" effect, the real exchange rate of fastgrowing countries typically appreciates. Therefore, the GDP PPP per worker path produced by the ENVLinkages model combines both a volume effect (GDP growth in constant national currency) and a relative price effect (the real exchange rate appreciation), with the former being the main driver of emissions.

\section{Assumptions about other drivers of emissions}

The BAU scenario was developed on the basis of the pre-crisis surge of the international crude oil price, and therefore assumed that it would culminate at USD 100 per barrel (in real 2007 prices) in 2008, stay constant in real terms up to 2020 and increase steadily thereafter up to USD 122 per barrel in 2030. Beyond that horizon, oil exporters' crude oil supply is projected to decelerate gradually, roughly reflecting reserve constraints, and resulting in a sustained rise in the real crude oil price beyond 2030 at $1 \%$ annually between 2030 and 2050. The international price of natural gas is assumed to follow the international crude oil price up to 2030, but this link then weakens somewhat, reflecting a higher assumed long-term supply elasticity for natural gas than for oil. Coal prices are projected to rise only modestly (in real terms) beyond their recent levels. The price of steam coal is assumed to reach USD 100 per tonne in 2008, in line with the assumption of a high long-term supply elasticity. International Energy Agency (IEA, 2008) energy demand projections were used to calibrate future energy efficiency gains. These assume a gradual weakening of the relationship between economic growth and energy demand growth, especially after 2030.

\section{Figure A2.1. Projected GHG emissions' by country/region (2005-50, Gt CO2eq)}

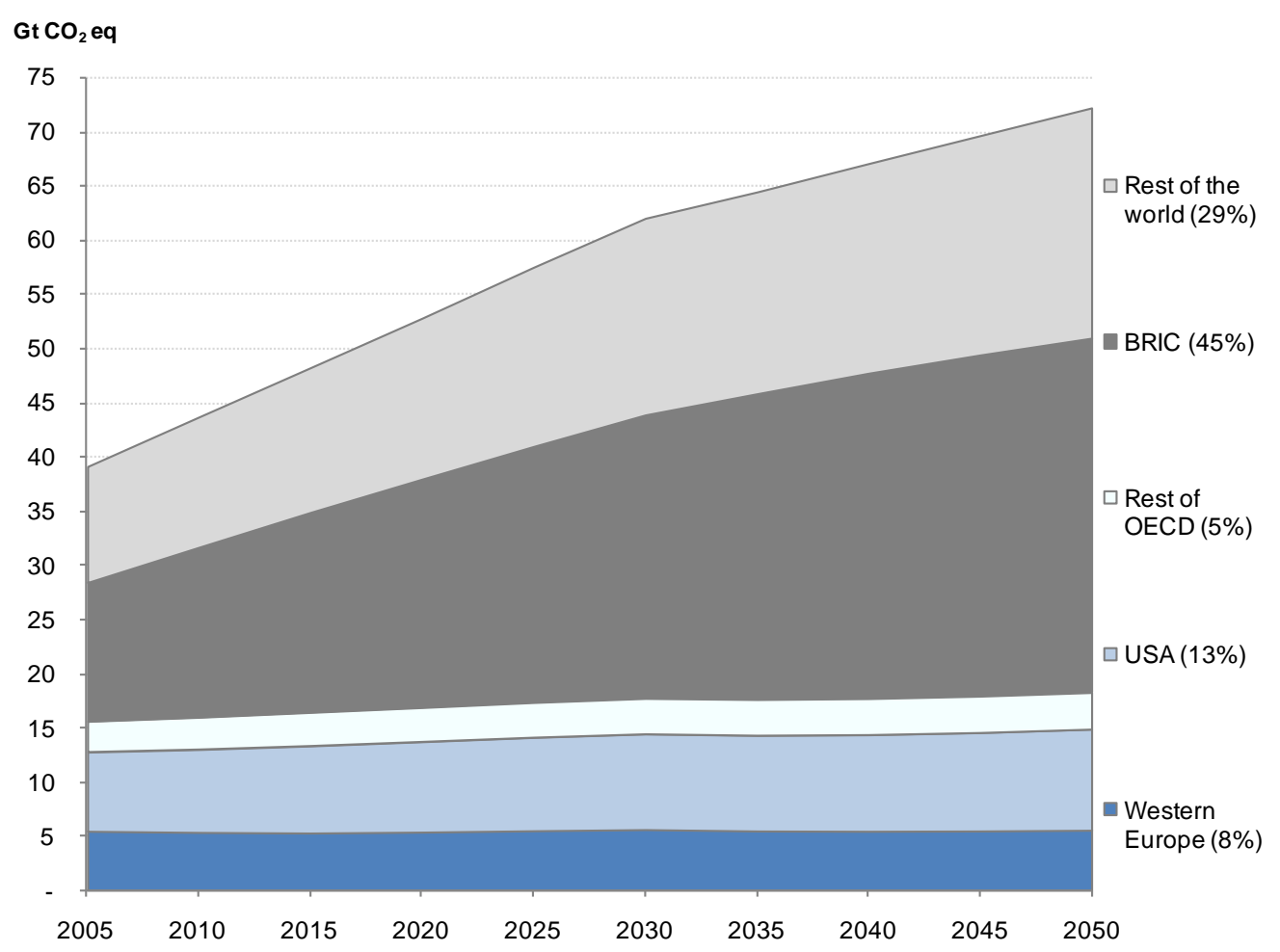

Note: Countries/regions in this figure are based on the 12-regions aggregation of the ENV-Linkages model. Korea, Mexico and Turkey are included in the Rest of the World (ROW).

1. Excluding emissions from Land Use, Land-Use Change and Forestry. Number in brackets represents percentage share of total emissions in 2050 . 
ECO/WKP(2010)50

\section{WORKING PAPERS}

The full series of Economics Department Working Papers can be consulted at www.oecd.org/eco/workingpapers/

793. Promoting potential growth: The role of structural reform

(July 2010) by Luiz de Mello and Pier Carlo Padoan

792. Catching-up and inflation in Europe: Balassa-Samuelson, Engel's law and other culprits (July 2010) by Balázs Égert

791. Do product market regulations in upstream sectors curb productivity growth? Panel data evidence for OECD countries (July 2010) by Renaud Bourlès, Gilbert Cette, Jimmy Lopez, Jacques Mairesse, Giuseppe Nicoletti

790. Preparing for Euro adoption in Poland

(July 2010) by Rafal Kierzenkowski

789. Gauging the impact of higher capital and oil costs on potential output (June 2010) by Boris Cournède

788. The German banking system: lessons from the financial crisis (June 2010) by Felix Hüfner

787. Measuring competition in Slovenian industries - estimation of mark-ups (June 2010) by Margit Molnar

786. Enhancing financial stability through better regulation in Hungary (June 2010) by Margit Molnar

785. Chile: Boosting productivity growth by strengthening competition, entrepreneurship and innovation (June 2010) by Cyrille Schwellnus

784. Chile: Climbing on giants' shoulders: better schools for all Chilean children (June 2010) by Nicola Brandt

783. Israel: Monetary and fiscal policy (June 2010) by Charlotte Moeser

782. Policy options for reducing poverty and raising employment rates in Israel (June 2010) by Philip Hemmings

781. Israeli education policy: How to move ahead in reform (June 2010) by Philip Hemmings

780. Germany's growth potential, structural reforms and global imbalances (June 2010) by Isabell Koske and Andreas Wörgötter

779 Energy policy and the transition to a low-carbon economy (June 2010) by Jeremy Lawson 
ECO/WKP(2010)50

778 Making the Luxembourg labour market work better (June 2010) by Jeremy Lawson

777 Coping with the job crisis and preparing for ageing: the case of Finland (June 2010) by Henrik Braconier

776. The political economy of fiscal consolidation (June 2010) by Robert Price

775. Structural and cyclical factors behind current-account balances

(May 2010) by Calista Cheung, Davide Furceri and Elena Rusticelli

774. A framework for assessing green growth policies

(May 2010) by Alain de Serres, Fabrice Murtin and Giusepppe Nicoletti

773. Modeling institutions, start-ups and productivity during the transition (May 2010) by Zuzana Brixiova and Balázs Égert

772. Can emerging asset price bubbles be detected? (June 2010) by Jesús Crespo Cuaresma

771. The nature of financial and real business cycles (2010) by Balázs Égert

770. The effects of fiscal policy on output: A DSGE analysis

(May 2010) by Davide Furceri and Annabelle Mourougane

769. Health care systems: efficiency and institutions

(May 2010) by Isabelle Joumard, Christophe André and Chantal Nicq

768. The OECD's new global model

(May 2010) by Karine Hervé, Nigel Pain, Pete Richardson, Franck Sédillot and Pierre-Olivier Beffy

767. Assessing the impact of the financial crisis on structural unemployment in OECD countries (May 2010) by Stéphanie Guichard and Elena Rusticelli

766. After the crisis: bringing German public finances back to a sustainable path (April 2010) by Isabell Koske

765. Optimal monetary and fiscal stabilisation policies

(May 2010) by Klaus Adam

764. Asset prices and real economic activity (May 2010) by E. Philip Davis

763. Fiscal policy reaction to the cycle in the OECD: Pro- or counter-cyclical? (May 2010) by Balázs Égert

762. New evidence on the private savings offset and Ricardian equivalence (May 2010) by Oliver Röhn 